\title{
Biodiversity of meiobenthic invertebrates in Lake Bardawil, Egypt.
}

\author{
Abd El-Halim A. Saad ${ }^{1}$;Magdy T. Khalil ${ }^{1}$; Mohamed R. Fishar ${ }^{2}$ and \\ Tadros Z. Bedir ${ }^{1}$ \\ 1- Zoology Dept., Faculty of Science, Ain Shams University, Egypt. \\ 2- National Institute of Oceanography \& Fisheries, Egypt.
}

\section{ABSTRACT}

Species composition, distribution of meiobenthic invertebrates in Baradwil Wetland were studied during 2006-2007. Seasonal samples were collected from 12 stations representing different habitats of the wetland. The results revealed that Thirteen species and 2 types of larval stages were identified in the lake (4 Foraminifera, 3 Copepoda, 2 Ostracoda, 2 Nematoda, one Tardigrada and one Mollusca). Ostracoda dominated the other groups forming $42.8 \%$ of total meiobenthos.

The population density of meiobenthos was obviously higher in eastern part of the lake, with a major peak of about $3780 \mathrm{Org} / 10 \mathrm{~cm}^{2}$ at station I, while the lowest crop of an average $942 \mathrm{Org} / 10 \mathrm{~cm}^{2}$ was found at station II. Regarding seasonal variation, there was a gradual increase in meiobenthos standing crop from minimum of $1103 \mathrm{Org} / 10 \mathrm{~cm}^{2}$ in summer until reaching a maximum of an average 3048 Org/ $10 \mathrm{~cm}^{2}$ in winter with an overall average of $1820 \mathrm{Org} / 10 \mathrm{~cm}^{2}$.

Fish community changes during the last two decades, which consequently changed the whole ecosystem of the lake, encourages us to recommend establishing a monitoring program to follow up changes in the lake ecosystem, especially the benthic fauna that will be of great help in the management of such important water body

Keywords: Bardawil Lake, Meiobenthos, Invertebrates, Biodiversity, Ecology, Egypt.

\section{INTRODUCTION}

Lake Bardawil is one of the five northern lakes in Egypt. It is bordered from the north by a convex sand barrier that separates it from the Sinai Mediterranean coast and from the south by the sand dune belt. The extreme eastern part of this lake (i.e. Zaranik Lagoon) is a Ramsar site and has been declared as a natural protectorate in 1985. This lake has an elliptical shape representing a major morphological feature along North Sinai coast. Its area is about 164,000 Feddan and extends for a distance of $80 \mathrm{~km}$ along $\mathrm{N}-\mathrm{S}$ axis. Its maximum width is $20 \mathrm{~km}$ and maximum depth is $3 \mathrm{~m}$. The main water body of this lake lies towards the east with an area of 58,000 Feddan of which Zaranik Lagoon occupies about 10,000 Feddan. Sea water enters the lagoon through three inlets: two artificial tidal inlets and a natural eastern inlet of Zaranik which is now occasionally closed by silting.

Lake Bardawil had been the subject of many studies during the last 20 years. Many theses, reports and papers had been published covering the geomorphology, morphometry, sedimentology, hydrology and water quality, macrophytes and phytoplankton, zooplankton and zoobenthos, fishes and fisheries, avifauna and others (Abdel-Daiem, 2000; Ali et al., 2006).

On the other hand, the benthic invertebrates in aquatic ecosystems play an important role in the transformation of the organic matter sediment on the bottom to 
its base elements and subsequently contribute to the basic nutrition of fish. The composition of the benthic fauna has largely been considered as a good indicator of water quality because, unlike planktonic species, they form relatively stable communities in the sediments which do not change over long time intervals and reflect characteristics of both sediments and upper water layer ( El-Shabrawy et al. 2003). Benthic invertebrates in aquatic ecosystems are divided according to the size, into macrobenthos and meiobenthos. meiofauna (meiobenthos) are small benthic animals with phylogenetic representation from almost all invertebrate phyla. They are regularly defined as those benthic metazoans passing through $500 \mu \mathrm{m}$ sieves but retained on meshes of 40-64 $\mu \mathrm{m}$ (Higgins \& Thiel, 1988). Meiofauna is not a homogeneous ecological group; but occupies a variety of habitats from Alpine lakes to deep-sea trenches. Meiobenthos comprises a ubiquitous, taxonomically diverse group with numerous components of the fauna of marine sediments (Coull, 1999) with a fast turnover, producing several generations a year. These animals facilitate remineralization of organic material and enhance bacterial activity (Tietjen, 1980). They are also important food for higher trophic levels (Gee, 1989; Castel, 1992). Meiobenthos are sensitive to anthropogenic disturbance and pollution (Coull \& Chandler, 1992; Warwick, 1993; Mirto et al. 2002) and their potential as indicators of environmental condition is widely recognized (Moore \& Bett 1989, Kennedy \& Jacoby 1999; Schratzberger et al. 2000). A number of studies have shown that their abundance and taxonomic diversity tend to decrease under conditions of great physical and chemical variability (Tietjen 1991; Coull 1999).

The objective of this work is to study species composition, biodiversity, and abundance of meiobenthic fauna community in relation to changes in some abiotic and biotic variables. As well as, following up long-term changes of this community in relation to some environmental changes.

\section{MATERIAL AND METHODS}

\section{Study area}

Lake Bardawil is a shallow, hypersaline lagoon (salinity $50.9 \%$ o), situated at the north of Sinai and occupying much of the Mediterranean coast of Sinai. Its coordinates are 310 09\ to $31003 \backslash \mathrm{N}$ latitude and $33019.25 \backslash$ to $32046.75 \backslash \mathrm{E}$ longitudes. It extends for about $80 \mathrm{~km}$ with a maximum width $20 \mathrm{~km}$ and a maximum depth of 3 meters. It is separated from the sea by sand bar that varies in width between 100 meters and $1 \mathrm{~km}$ (Figure 1). The lake shore is mainly bare sand, with scattered salt marsh and mudflats.

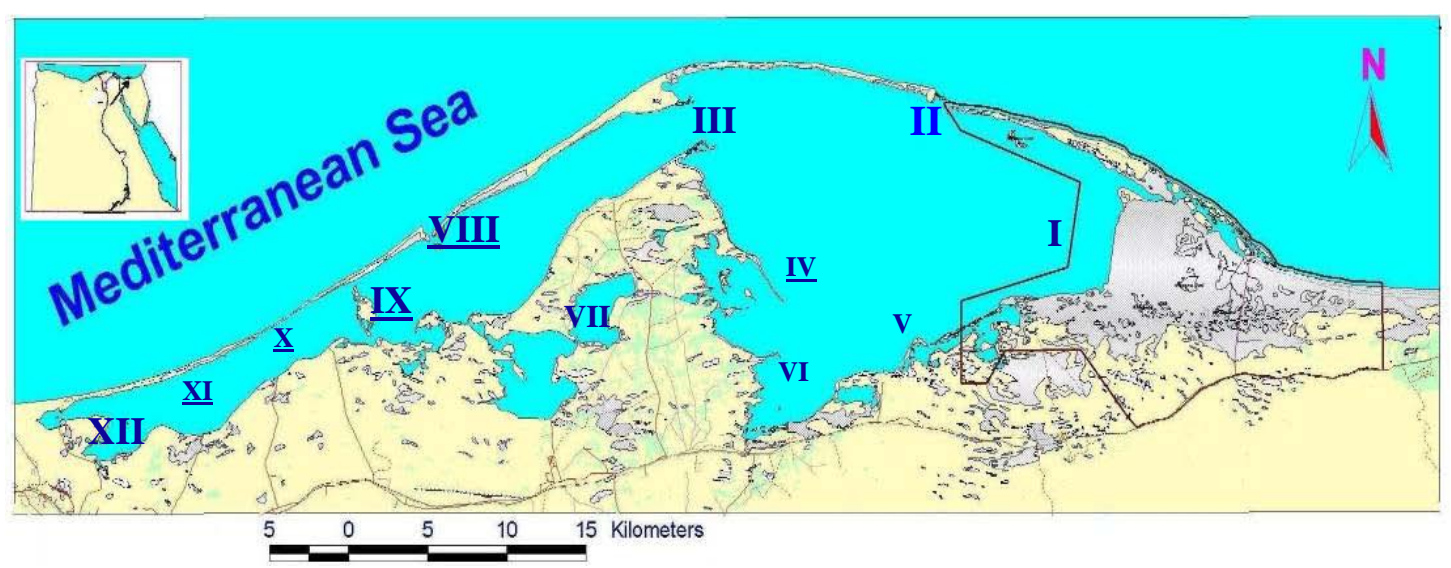

Fig. 1: A Map Showing the Location of Bardawil Lagoon and the Selected Stations 


\section{Sampling Programme and stations}

Water and macrobenthic samples were seasonally collected from spring 2006 to winter 2007 from 12 stations which have been selected to represent different habitats of the Lake Bardawil (Table 1 and Figure 1).

Table 1: Location of Sampling Stations in Lake Bardawil

\begin{tabular}{|c|c|c|c|c|}
\hline \multicolumn{2}{|c|}{ St. No. } & Name & Latitude & Longitude \\
\hline \multirow{6}{*}{ 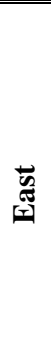 } & I & Karn-Hamda & $31^{0} 09^{\prime} 18^{\| \prime}$ & $33^{0} 19^{\prime} 25^{\backslash \prime}$ \\
\hline & II & Boughaz II & $31^{0} 12^{\prime} 27^{\prime \prime}$ & $33^{0} 15^{\backslash} 43^{\prime \prime}$ \\
\hline & III & El-Kals & $31^{0} 11^{\backslash} 78^{\|}$ & $33^{0} 06^{`} 24^{\prime \prime}$ \\
\hline & IV & El-Aofra & $31^{0} 08^{\backslash} 96^{\prime \prime}$ & $33^{0} 07^{\backslash} 92^{\prime \prime}$ \\
\hline & $\mathrm{V}$ & El-Telul & $31^{0} 04^{\backslash} 50^{\|}$ & $33^{0} 10^{\backslash} 13^{\|}$ \\
\hline & VI & Mitzfag & $31^{0} 05^{\prime} 81^{\prime \prime}$ & $33^{0} 13^{\backslash} 65^{\prime \prime}$ \\
\hline \multirow{6}{*}{$\sum_{\overrightarrow{3}}^{\vec{b}}$} & VII & El-Rooc & $31^{0} 05^{`} 35^{\prime \prime}$ & $32^{0} 59^{\backslash} 18^{\prime \prime}$ \\
\hline & VIII & Boughaz I & $31^{0} 08^{\prime} 11^{\prime \prime}$ & $32^{0} 55^{\prime} 75^{\prime \prime}$ \\
\hline & IX & Romea & $31^{0} 06^{\backslash} 12^{\|}$ & $32^{0} 53^{\backslash} 30^{\|}$ \\
\hline & $X$ & El-Nasr & $31^{0} 05^{`} 67^{\prime \prime}$ & $32^{0} 51^{\backslash} 18^{\prime \prime}$ \\
\hline & XI & Nedjela & $31^{0} 04^{\prime} 20^{\prime \prime}$ & $32^{0} 48^{\backslash} 36^{\prime \prime}$ \\
\hline & XII & Raba'a & $31^{0} 03^{\prime} 51^{\prime \prime}$ & $32^{0} 46^{\backslash} 75^{\backslash}$ \\
\hline
\end{tabular}

\section{Meiobenthos}

Seasonal meiobenthic samples were collected using Ekman Grab $\left(225 \mathrm{~cm}^{2}\right.$ opening area). The collected samples were preserved in $4 \%$ formaldehyde solution.

In the laboratory, the collected meiofauna samples were passed through two sieves; the top one with a mesh opening of $500 \mu \mathrm{m}$ (captured the macrofauna) and the bottom one with a mesh opening of $55 \mu \mathrm{m}$ for retaining meiofauna.

The samples were stained with Rose Bengal. Quantitative analysis of meiofaunal composition was carried out under binocular microscope for sorting and identification to the species or high taxa level. Results were given as the total number of individuals per $10 \mathrm{~cm}^{2}$.

\section{Physical and chemical parameters}

Transparency was measured by Secchi disk (SD) $(25 \mathrm{~cm}$ in diameter). Water temperature and dissolved oxygen were measured at the sampling sites during the day time, using an oxygen meter (model YSI 58) equipped with a temperature sensor. The $\mathrm{pH}$ values were measured using glass electrode $\mathrm{pH}$ meter (digital minicomputer $\mathrm{pH}$ meter model Carrning 354). Nitrogen compounds (nitrate-nitrogen) were measured by phenol-disulphonic acid method according to Cooper (1990). Spectrophotometer used was of model Milton Roy 21D. Dissolved orthophosphate was measured using Spectrophotometer (model Milton Roy 21D).

\section{RESULTS AND DISCUSSION}

\section{Physical and chemical properties of water Water Temperature}

The recorded values of water temperature at the surveyed stations fluctuated between $28.30 \mathrm{C}$ in the summer to $18.90 \mathrm{C}$ in winter and dropped to a minimum of 17.3 0C at station II (Boughaz II) in the same seasons and gradually increased until 
reached maximum of 33.9 OC at station VII in spring season. The same results obtained by Ali et al. (2006).

\section{Transparency}

Turbidity of lake water is caused by mineral or organisms particles in suspension. Mineral turbidity is composed of clay and silt particles, while organic turbidity is made up of planktonic organisms. Lake Bardawil water shows high visibility values that fluctuated between $121 \mathrm{~cm}$ in winter and $175 \mathrm{~cm}$ in spring. An average annual maximum and minimum values of Secchi disc readings reached 227.5 $\mathrm{cm}$ at station IX and $89 \mathrm{~cm}$ at station III respectively. The highest turbidity, which was observed in winter, is mainly due to continuous mixing of the lagoon water by the strong wind action which prevails in this seasons and the phytoplankton blooming in autumn. On the contrary, the highest transparency found in summer is mainly due to the stability of the lagoon water, which resulted from the decrease of wind speed (Siliem, 1989a). The same results were recorded during 2006/2007 season.

\section{Total dissolved solids}

Total dissolved solids (TDS) in Bardawil lagoon fluctuated within a high range of 49.8 - $37.1 \mathrm{~g} / \mathrm{l}$, with an average value of $44.2 \mathrm{~g} / \mathrm{l}$. The regional average values showed high differences at all regions of the lagoon; maximum and minimum values; 67.0 and $33.5 \mathrm{~g} / \mathrm{l}$ were recorded at stations I during summer 2006 and station III during autumn 2006 respectively. The seasonal average of total dissolved solids showed a maximum value in summer 2006 of $48.3 \mathrm{~g} / \mathrm{l}$ to a minimum value in winter 2007 of about $41.5 \mathrm{~g} / \mathrm{l}$.

During 1970's Ben-Tuvia (1979), pointed that, total dissolved solids exceeded $100 \mathrm{~g} / \mathrm{l}$ due to the two artificial inlets were completely closed. During 1980's the value gradually decreased due to re-opening of the two inlets after Liberation of Sinai; it reached to about $90 \mathrm{~g} / \mathrm{l}$ (Siliem, 1989a). During 1990's, Abdel-Daiem (2000) and Shabana (1999), showed that the total dissolved solids values fluctuated between 40.0 - $81.5 \mathrm{~g} / \mathrm{l}$ and 44 - $74 \mathrm{~g} / \mathrm{l}$ respectively.

\section{Salinity}

The salinity of Bardawil Lagoon is much higher than in the open sea as a result of low rainfall (80 - $100 \mathrm{~mm} /$ year) and high evaporation rate (1460 mm/year). Therefore, the calculated net water loss by Euroconsult (1995), is about 2.2 million $\mathrm{m} 3$ per day compensated by the inward flows through the inlets. The climatic conditions play a major role in influencing the salinity of lake. The salinity of lagoon shows relative variation with the distance from the two artificial openings with the Mediterranean Sea. Moreover, it shows pronounced annual changes, with the lowest salinities during winter, and highest one during summer.

The same author found that the level of the salinity in the lagoon is the state of the openings. However, in the period of partial closure of the openings by sand, the salinities are higher than after dredging. These inlets have natural tendency to be closed by sand carried along the coast by waves and eastward coastal current at a rate of 300,000 to $500,000 \mathrm{~m} 3$ per year. The tidal flow through the two inlets is too weak to keep them open, so continuous dredging is needed during the year to remove accumulated sand by the General Authority for Fish Resources Development (Ministry of Agriculture).

During 1969 till 1971 the two openings were completely blocked by the accumulated sand. Consequently, the salinities of the Lagoon rose considerably reaching to about $100 \%$ and in some isolated basin the salinity reached up to $170 \%$ (Ben-Tuvia, 1979; Krumgalz et al., 1980). During 1990's the salinity values decreased gradually after dredging and re-opening of the two inlets, it reached to about $78 \%$ 
(Shabana, 1999). The salinity values fluctuated between 54 to 68 \%o during 2000 (Toulibah et al., 2002). During 2004, salinity varied between minimum values of 38.5 \%o during winter at Boughaz II area to maximum of 74.5 \%o during summer at the most western part of the Lagoon (Ali et al., 2006).

\section{Hydrogen Ion Concentration (pH)}

The hydrogen ion concentration $(\mathrm{pH})$ in the studied area were always on the alkaline side and fluctuated within a narrow range of about $7.6-8.3$ with an average value of 8.1. The regional average $\mathrm{pH}$ values showed high differences at all regions in the lagoon. A minimum and maximum values of about 7.1 and 8.8 were recorded at stations I during summer 2006 and station V during winter 2007 respectively.

The recorded $\mathrm{pH}$ levels were in agreement with those obtained by Siliem, (1989a), who recorded values that ranged between $7.5-8.76$ with an annual average of 8.16. It is notable that, $\mathrm{pH}$ values showed slight variation among different stations and months. However, $\mathrm{pH}$ values increased slightly during spring which was attributed to photosynthetic activity, which reduced the CO2 amount in water (ElWakeel and Wahby (1970). While the decrease of $\mathrm{pH}$ values during summer and early autumn may be attributed to bacterial fermentation and decomposition of organic matter (Saad, 1973).

\section{Dissolved oxygen}

Dissolved oxygen is one of the ecological factors key of life. Moreover, dissolved oxygen is much more important to aquatic than to terrestrial life as oxygen has a low solubility in water and is often a limiting factor for life in water. Also, oxygen is needed for all oxidation, nitrification and decomposition processes and it is controlled by some factors: respiration, photosynthesis and exchange at the air water interface. On the other hand, oxygen is the most fundamental parameter of lakes, aside from water itself.

The regional average values of DO fluctuated within a wide range of about $5.3-$ $6.6 \mathrm{mg} / \mathrm{l}$ with an average of $5.8 \mathrm{mg} / \mathrm{l}$. The minimum value of DO was recorded at station I during summer 2006, and the maximum value $10 \mathrm{mg} / \mathrm{l}$ was recorded at station II during winter 2007. The low average value of DO was recorded during summer 2007 (2.7 mg/l), while the highest value was recorded during winter 2007 (7.9 mg/l). The same values were recorded by Barbary and El-Shabrawy (2004).

Khalil and Shaltot (2006) stated that water of Bardawil Lagoon is well oxygenated during different time intervals. The minimum DO value of $4.8 \mathrm{mg} / \mathrm{l}$ was recorded at station VI during July while the maximum of $10.2 \mathrm{mg} / \mathrm{l}$ was recorded at station I during January, with annual mean value of $7.3 \pm 0.9$. Dissolved oxygen values showed relative decrease during hot months which was mainly attributed to elevation of temperature that led to decrease the solubility of oxygen gas (Rai, 2000), in addition to water salinity increase during summer affect adversely on the solubility of oxygen gas (Weiss, 1970). On the other hand, the increase of DO during cold months mainly due to decreasing of temperature, prevailing winds action which permits to increase the solubility of atmospheric oxygen gas (Romairo, 1978).

\section{Nutrient salts}

Nutrient salts are dissolved mineral salts, include phosphorus (P), nitrogen $(\mathrm{N})$ and silica $(\mathrm{Si})$. The nitrogenous salts are nitrates $\left(\mathrm{NO}_{3}\right)$, nitrites $\left(\mathrm{NO}_{2}\right)$ and ammonia $\left(\mathrm{NH}_{4}\right)$.

\section{Nitrite $\left(\mathrm{NO}_{2}-\mathrm{N}\right)$}

Nitrites depleted completely in some stations B. Logo. The annual average value of nitrite was $4.5 \pm 3.3 \mu \mathrm{g} / \mathrm{l}$, while the highest value of nitrite $(19.2 \mu \mathrm{g} / \mathrm{l})$ was recorded 
at station I (El-Telul region) during winter due to pollution point at this station represented in tailings of fishermen. The biological reduction of nitrite in the lagoon due to the uptake of nitrite into cellular amino acids by the photosynthesis of plankton, and by the action of transaminase enzyme, which decrease the nitrite, values in the studied area (Siliem, 1989), reported that nitrites were completely depleted during his study with some exception during winter, spring and autumn in some stations.

\section{Nitrate $\left(\mathrm{NO}_{3}-\mathrm{N}\right)$}

The minimum value of nitrate $13 \mu \mathrm{g} / \mathrm{l}$ was recorded during November at station XII while the maximum value of $89 \mu \mathrm{g} / \mathrm{l}$ was recorded during January at Boughaz I area, with annual average of $42 \pm 15 \mu \mathrm{g} / \mathrm{l}$ (Ali et al., 2006), stated that the nitrate in Bardawil Lagoon showed that the nitrate concentration increased during spring and summer which was mainly attributed to the oxidation of ammonia yielding nitrate especially in abundant oxygen and phytoplankton during spring. Furthermore, the annual average values showed a noticeable increase of nitrate content westward at stations XI and XII which may be due to dense abundance of sea grasses in these areas, besides an expected increase at El-Telul area as a consequence of fishermen tailings in this region.

\section{Ammonia ( $\left.\mathrm{NH}_{4}+-\mathrm{N}\right)$}

The maximum ammonia value of $138 \mu \mathrm{g} / \mathrm{l}$ was recorded at station I (El-Telul area) during September while the minimum value of $9 \mu \mathrm{g} / \mathrm{l}$ was recorded at station XI during February, with annual mean value of $48 \pm 11 \mu \mathrm{g} / \mathrm{l}$. Ammonia contents in Bardawil Lagoon showed homogeneous distribution with narrow horizontal fluctuations except station I which suffers from different pollution aspects. The regional average values showed a notable increase of ammonia concentration during summer and early autumn which was controlled by two important processes; ammonification and denitirfication. The two processes are not only temperature dependent but are also dependent largely on available organic substrate.

\section{Orthophosphate ( $\left.\mathrm{PO}_{4}-3-\mathrm{P}\right)$}

The maximum orthophosphate value of $90 \mu \mathrm{g} / \mathrm{l}$ was recorded at station IX during April while the minimum value of $10 \mu \mathrm{g} / \mathrm{l}$ was recorded at station III during December, with an annual mean value of $35 \pm 12.4 \mu \mathrm{g} / \mathrm{l}$. The orthophosphate contents in Bardawil Lagoon showed relative increases during spring and summer more than in other seasons. This phenomenon attributed to decomposition of organic matter, leads to liberating phosphorus as one of the breakdown products, and the mobilization of phosphorus from sediments under microbial activities, especially in the presence of dissolved oxygen since, it plays an important role in controlling the rate of phosphate released from sediments to the photic zone (Siliem, 1989). The relative decrease of orthophosphate content during autumn, and winter attributed to its sorption on to the humic matter forming humic- iron - phosphate complexes $\left(\mathrm{DHM}-\mathrm{Fe}-\mathrm{PO}_{4}\right)$; this reduces the total amount of available phosphate.The regional average values showed that, Boughazes (inlets) areas have the higher orthophosphate contents, it decreased gradually southward. This observation indicated that orthophosphates were transported from see water into the lagoon and consequently precipitated due to higher salinity of lagoon water than the sea water. Phosphorus forms chemically tight compounds with major cations enriched in the lagoon, these tight forms especially with magnesium (in the form of $\mathrm{MgPO}_{4} ; \mathrm{MgHPO}_{4}$ and $\mathrm{MgH}_{2} \mathrm{PO}_{4}$ ) and calcium (in the form of $\mathrm{CaPO}_{4} ; \mathrm{CaHPO}_{4}$ and $\mathrm{CaH}_{2} \mathrm{PO}_{4}$ ). Besides lesser values of free not-bound $\mathrm{HPO}_{4}$ and $\mathrm{H}_{2} \mathrm{PO}_{4}$ radicals which depend on the $\mathrm{pH}$ variations (Pulmmer et al., 1984). 


\section{Meiobenthos}

\section{Community composition}

A total of 15 taxa of living meiobenthic invertebrates were identified in the collected benthic samples of Lake Bardawil during 2006 - 2007. These include 4 Foraminifera, 2 Ostracoda, 2 Nematoda, 3 Copepoda, one of Tardigrad species, two types of larval stages and one mollusk (Table 2). Ostracoda was represented by 42.8 $\%$ of total species followed by Foraminifera $32.7 \%$, Nematoda $14.1 \%$ and copepoda $5.8 \%$ (Fig. 2). Ratio of polychaet larvae, Nauplius larvae, Lanthania sp. of Mollusca and Tardigrad species were very few representing $4.5 \%$ of total meiobenthic fauna. In addition, there were different uncommon meiobenthic forms (like Capitella, appendages of crustacean, eggs and embryos of fish, and Gnathostomulida).

Table 2: Check list of meiobenthic fauna of Lake Bardawil during different intervals

\begin{tabular}{|c|l|c|c|}
\hline \multirow{2}{*}{ Group } & \multicolumn{1}{|c|}{ Species } & Fishar (2004) & $\begin{array}{c}\text { Present study } \\
\mathbf{2 0 0 6 / 2 0 0 7}\end{array}$ \\
\hline \multirow{4}{*}{ Foraminifera } & Elphidium sp. & + & + \\
\cline { 2 - 4 } & Ammonia sp. & + & + \\
\cline { 2 - 4 } & Quinqueloculina sp. & + & + \\
\cline { 2 - 4 } & Trochammina sp. & + & + \\
\hline \multirow{3}{*}{ Nematoda } & Thormella teres & + & + \\
\cline { 2 - 4 } & Rhabditis marina & + & + \\
\cline { 2 - 4 } & Enoplus meridionalis & + & + \\
\hline Tardigrada & Tardigrad sp. & + & + \\
\hline Polychaeta & Larvae of Polychaeta & + & + \\
\hline \multirow{3}{*}{ Copepoda } & Euterpina acutifrons & + & + \\
\cline { 2 - 4 } & Harpacticus sp. & + & + \\
\cline { 2 - 4 } & Cyclopoid copepoda & + & + \\
\cline { 2 - 4 } & Nauplius larvae & + & + \\
\hline \multirow{2}{*}{ Ostracoda } & Cyprideis torosa & + & + \\
\cline { 2 - 4 } & Aglaiocypris sp. & + & + \\
\hline Gnathostomulida & Austrogmathda sp. & & + \\
\hline Mollusca & Lanthina communis & & + \\
\hline
\end{tabular}

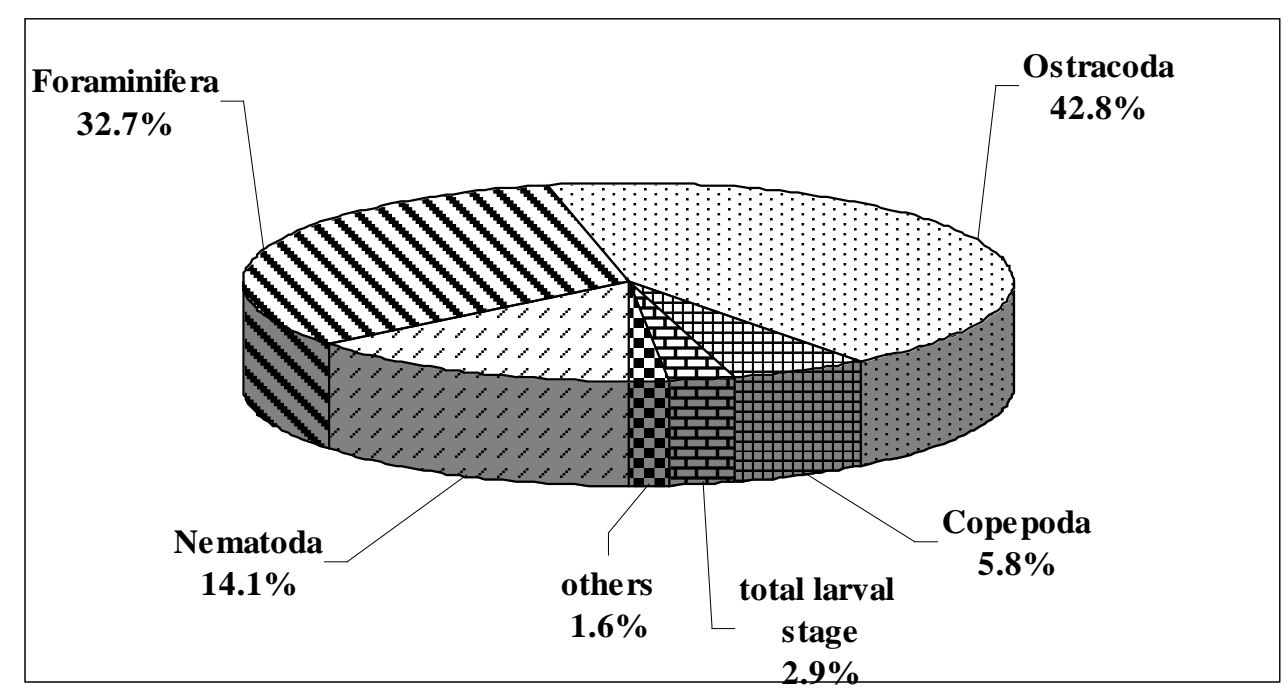

Fig. 2: Community composition of total meiobenthos fauna in Lake Bardawil during 2007. 


\section{Seasonal variation}

Concerning seasonal variation of meiobenthos, the highest population density was recorded during winter (2007) with an average of $3048 \mathrm{Org} / 10 \mathrm{~cm}^{2}$. A remarkable decrease was recorded during summer (2006) to reach $1103 \mathrm{Org} / 10 \mathrm{~cm}^{2}$ and moderate decrease was recorded during autumn (2006) to reach $1722 \mathrm{Org} / 10 \mathrm{~cm}^{2}$. The results showed that maximum abundance of meiobenthos was observed in the cold months that attributed to abundance of food supply (benthic primary productivity) rather than high reproductive and development rates. The same observation was reported for meiobenthic community of Wadi El-Rayan Lakes (Fishar and Abdel-Gawad, 2004).

\section{Distribution}

The annual average density of total meiobenthos was $1820 \mathrm{Org} / 10 \mathrm{~cm}^{2}$. The highest density was recorded at stations I and IV with average values of 3780 and 2989 Org $/ 10 \mathrm{~cm}^{2}$ respectively.

On the other hand, the lowest average values were recorded at stations VIII and II with average values of 652 and $942 \mathrm{Org} / 10 \mathrm{~cm}^{2}$ respectively. This value is higher than that recorded in the same lake which means improvement of ecological conditions suitable to meiobenthos. This value also higher than that recorded in Egyptian lakes; 1495 Org/10 cm² in Lake Manzalah (Fishar, 1999), 609 Org/10 cm² in Lake Qarun (Fishar, 2000) and 257, 274 Org/10 $\mathrm{cm}^{2}$ in Upper and lower respectively (Fishar \& Abdel-Gawad, 2004).

\section{Ostracoda}

Ostracoda was the first common dominant group of meiobenthic fauna in all seasons and stations of the lake, comprising about $42.8 \%$ of total population density .Two species of Ostracoda were recorded; Agaliocypris sp., which was represented by $69 \%$ of total community followed by Cyprideis torosa, which was represented by 31 $\%$ only. Concerning seasonal variations of Ostracoda, the highest population density was recorded during winter 2007 with an average value of $1298 \mathrm{Org} / 10 \mathrm{~cm}^{2}$ ). A moderate decrease was recorded during autumn 2006 which reached to 771 Org/10 $\mathrm{cm}^{2}$ and remarkable decrease was recorded during spring and summer 2006 with average values of 257 and $324 \mathrm{Org} / 10 \mathrm{~cm}^{2}$ respectively.

The annual average density of total Ostracoda was $671 \mathrm{Org} / 10 \mathrm{~cm}^{2}$. The highest density was recorded at stations XII and XI with average values of 1363 and 1313 Org $/ 10 \mathrm{~cm}^{2}$ respectively. On the other hand, the lowest density was recorded at stations VIII and III with average values of 217 and 259 Org/10 $\mathrm{cm}^{2}$ respectively.

The distribution of Ostracoda is apparently with sediment analysis. Giere (1993) stated that ostracods usually live in fine or shelly sand and burrowing and pushing through the sediment with strong legs and prefer the surface sediment layer of shallow bottoms. The same observation was recorded in our study.

Ostracoda group shows a positive correlation with total dissolved salts $(\mathrm{r}=0.71)$ and showed a negative correlation with dissolved oxygen $(r=-0.50)$.

\section{Foraminifera}

Foraminifera was the second common dominant group of meiobenthic fauna in all seasons and stations of the lake, comprising about $32.7 \%$ of total population density.Four species of Foraminifera were recorded; Quinqueloculina spp., Ammonia spp.; Trochammina spp. and Elphidium spp. which were represented by $49.8 \%$, $31.9 \%, 14.8 \%$ and $3.5 \%$ of total community composition of foraminifera fauna respectively.

Concerning seasonal variations of Foraminifera, the highest population density was recorded during winter 2007, which reached to about $1135 \mathrm{Org} / 10 \mathrm{~cm}^{2}$ and a 
remarkable decrease was recorded during summer 2006 an average value of 125 Org/ $10 \mathrm{~cm}^{2}$.

The annual average density of total Foraminifera was $513 \mathrm{Org} / 10 \mathrm{~cm}^{2}$. The highest density was recorded at stations I and IV with average values of 1547 and $1120 \mathrm{Org} / 10 \mathrm{~cm} 2$ respectively. On the other hand, the lowest density was recorded at stations VIII and IV with average values of 161 and $154 \mathrm{Org} / 10 \mathrm{~cm}^{2}$ respectively. These results agree with Heinz et al. (2004) who explained that foraminiferan assemblages showed their highest abundance at sites of coarser and sandy substrata of Great Meteor Seamount

Foraminifera shows a positive correlation with nitrites and ammonia $(r=0.83$ and 0.94) and showed a negative correlation with orthophosphates $(r=-0.07)$.

\section{Nematoda}

Nematoda was the third common dominant group of meiobenthic fauna of the lake, comprising $14.1 \%$ of total population density. Two species of Nematoda were recorded; Enoplus meridionalis and Rhabditis marina which were represented by 87.7 and $12.2 \%$ of total community composition of Nematoda respectively.

Concerning seasonal variations of Nematoda, the highest population density was recorded during spring 2006 which reached to $507 \mathrm{Org} / 10 \mathrm{~cm}^{2}$ ) and gradual decrease of population density during summer and autumn 2006 with an average values of 374 and $175 \mathrm{Org} / 10 \mathrm{~cm} 2$ respectively. The density reincreased gradually during winter and spring 2007 with average values of 292 and 303 Org/10cm2 respectively.

The annual average density of total Nematoda was $330 \mathrm{Org} / 10 \mathrm{~cm}^{2}$. The highest density was recorded at stations VI and I with average values of 595 and 553 Org $/ 10 \mathrm{~cm}^{2}$ respectively. On the other hand, the lowest density was recorded at stations XI and XII with average values of 118 and $49 \mathrm{Org} / 10 \mathrm{~cm}^{2}$ respectively.

The results showed that high abundance was recorded in polluted site (site I) due to human activity. The same observation was recorded by Bowman (1984). He stated that the nematods density increase in slightly polluted sites and nematods more tolerant to moderate pollution and lower oxygen content than other taxa.

In Lake Bardawil ammonia showed a positive correlation with nematode ( $\mathrm{r}=$ 0.43).

\section{Copepoda}

Copepoda was the fourth common dominant group of meiobenthic fauna of the lake, comprising $5.8 \%$ of total population density. Three species of Copepoda were recorded; Harpacticus sp., Cyclopoid copepoda and Euterpina actuiferous, which were representing by $61.1 \%, 27.7 \%$ and $11.2 \%$ of total Copepoda respectively.

Concerning seasonal variations of Copepoda, the highest population density was recorded during spring 2006 with an average value of $271 \mathrm{Org} / 10 \mathrm{~cm} 2$ and then decreased during summer and autumn 2006 with average values of 210 and 181 Org/ $10 \mathrm{~cm} 2$ respectively. The density reincreased gradually during winter and spring 2007 with average values of 228 and 280 Org/10cm2 respectively.

The annual average density of total Copepoda was $234 \mathrm{Org} / 10 \mathrm{~cm} 2$. The highest density was recorded at stations $\mathrm{X}$ and I with average values of 679 and 654 Org $/ 10 \mathrm{~cm} 2$ respectively. On the other hand, the lowest density was recorded at stations XII and VIII with average values of 21 and 42 Org/10 cm2 respectively.

Copepoda showed a positive correlation with nitrites and ammonia $(r=0.57$ and 0.59 respectively).

The change in fish community of Lake Bardawil during the last decade, which consequently changes the whole ecosystem of the lake, encourages us to recommend establishing a monitoring program to follow up changes in the lake ecosystem, 
especially the benthic fauna that will be of great help in the management of such important water body.

\section{REFERENCES}

Abdel-Daiem, A. A. (2000). Morphological and hydrochemical characteristics of Bardawil lagoon in comparison with that of Manzala Lagoon, Northern Egypt. J. of Environ. Sci., 20: $177-200$.

Aboul-Ezz, S.M. (1988). Periodicity and distribution of bottom fauna in the hypersaline Bardawil lagoon. Bull. Nat. Inst. Ocean. \& Fish., 14(1): 159 - 174.

Ali, M. H. H.; Sayed, M. F. and Goher, M. E. (2006). Studies of water quality and some heavy metals in hypersaline Mediterranean Lagoon (Bardawil Lagoon, Egypt). Egypt. J. of Aquat. Biol. \& Fish., 10 (4): 45-64.

Barbary, M. S. A. and El-Shabrawy, G. M. (2004). Community structure and biochemical parameters of annelid worms in Bardawil Lagoon. J. Egypt. Ger. Soc. Zool., 45(D):469492.

Ben-Tuvia, A. (1979). Studies of the population and fisheries of Sparus aurata in the Bardawil Lagoon, Eastern Mediterranean. Inv. Pesq., 431: 43 - 67.

Broberg, O. and Persson, G. (1988). Particulate and dissolved phosphorus forms in freshwater: Composition and analysis. Hydrobiol., 170: 61 - 90.

Cole, G.A. (1979). Text book of limnology. $2^{\text {nd }}$ Edition, St. Louis, Toronto, London, C.V. Mosby Company,.

Cooper, A.B. (1990). Nitrate depletion in the riparian zone and stream channel of a small headwater catchment. Hydrobiol., 202: 13-26.

El-Shabrawy, G.M. and Khalil, M. T. (2003). Macrobenthos of Lake Bardawil and Zaranik Lagoon. A report presented to Nature Conservation Sector, EEAA. Med Wet Coast Project, Conservation of Wetland and Coastal Ecosystems in the Mediterranean Region, Ecological Survey of Zaranik Nature Protectorate, GEF, 30 pp.

El-Shabrawy, G.M. and Rizk, E.T. (2005). Long-term changes and community structure of macrobenthic Arthropoda and Mollusca in Bardawil Lagoon. Thalassia Salentina. 28: 17-30.

El-Wakeel, S. K. and Wahby, S. D. (1970). Hydrography and chemistry of Lake Manzalah, Egypt, Arch. Hydrobiol., 67: 173- 200.

Euroconsult, (1995). In association with Delft Hydraulic, BLDP, Management of the environmental parameters, Netherland.

Fishar, M. R. A. (1999). Distribution and abundance of benthic assemblages in El-Gamil Basin (Lake Manzalah, Egypt) a- Meiobenthos. Bull. Nat. Inst. Oceangr. \& Fish., 25: 151- 166.

Fishar, M.R.A. (2005). Ecology of benthic communities of Lake Bardawil, Egypt. B. Macrobenthos. J. Aquat. Biol. \& Fish., 9 (2):53-71.

Fishar, M. R. A. and Abdel Gawad, S. S. (2004). Ecology of meiobenthic fauna in Wadi ElRaiyan Lakes, Fayoum, Egypt. J. Egypt. Ger. Soc. Zool., 45(D): 23-35.

Flint, R.W. (1979). Responses of freshwater benthos to open-lake dredge spoils in Lake Erie. J. Great Lakes Res., 5(3-4):264-275.

Fouda, M.M.; Wanes, M.K. and Saleh, M.A. (1985). Ecology of Bradawil lagoon. A report to the Oil Pollution Res. Unit, Pembroke, U.K. for B.P Petroleum Ltd. Egypt.

Khalil, M. T. and Shaltot, K. (2006). Lake Bardawil; Zaranik Protected Area. EEAA,

Krumgalz, B. S.; Horunung, H. and Oren, O. H. (1980). The study of a natural hypersaline lagoon in a desert area Bardawil Lagoon in Northern Sinai. Estuarine and Coastal Marine Science, 10: $403-415$.

Pulmmer, J.; Jones, B. and Truesdell, A. (1984). WATEQ-A FORTRAN IV version of WATEQ, a computer program for calculating chemical equilibrium of natural waters. Water Resources Investigations U.S. Geological Survey, 76: 31p0. 
Rai, A. K. (2000). Limnological characteristics of subtropical Lakes Phewa, Begnas and Rupa in Pokhara Valley, Nepal. Jpn J. Limnol., 1: 33 - 46.

Reynoldson, T. B.; Bailey, R. C.; Day, K. E. and Norris, R. H. (1995). Biological guidelines for freshwater sediment based on benthic assessment of sediment (beast) using a multivariate approach for predicting biological state. Aust. J. Ecol., 20 (1):198-220.

Reynoldson, T. B. and Zarull, M. A. (1989). The biological assessment of contaminated sediments-the Detroit River example. In Environmental Bioassay Techniques and Their Application, eds. M. Munawar, G. Dixon, C.I. Mayfield, T. Reynoldson, and M.H. Sadar, 463-476 pp. Belgium: Kluwer Academic Publishers.

Romairo, R. P.; Boyd, C.E. and Collins, W. J. (1978). Predicting nighttime dissolved oxygen decline in ponds used for Tilapia culture. Trans. m. Fish. Soc., 107: 804-808.

Rosenberg, D. M. and Resh, V. R. (1993). (Editors) Freshwater biomonitoring and benthic macroinvertebrates. New York; Chapman and Hall, 488 pp.

Saad, M. A. H. (1973). Some Limnological characteristics of the Nozha Hydrodrom near Alexandria, Egypt. Hydrobiol., 41: 477-499.

Shabana, E. E. (1999). Limnological studies on Lake Bardawil. M.Sc. Thesis fac. Sci. Suez Canal Univ., 135 pp.

Siliem, T. A. A. (1989a). The chemical conditions in Bardawil Lagoon. III-Some limnological studies. Bull. Nat. Inst. Oceanogr. \& Fish. ARE., 15: 21-33.

Siliem, T. A. A. (1989b). The chemical conditions in Bardawil Lagoon. IV-Nutrient salts. Bull. Nat. Inst. Oceanogr. \& Fish. ARE., 15: 217 - 228.

Toulibah, H.; Shfik, H.M.; Gab-Allah, M.M. and Taylor, W.D. (2002). Phytoplankton and some abiotic features of El-Bardawil Lake, Sinai Egypt. Afr. J. Aqu. Sci., 27: 97 - 105.

Weiss, R. F. (1970). The solubility of nitrogen, oxygen and argon in water and sea water. Deep. Sea. Res., 17: 721 - 735.

\section{ARABIC SUMMARY}

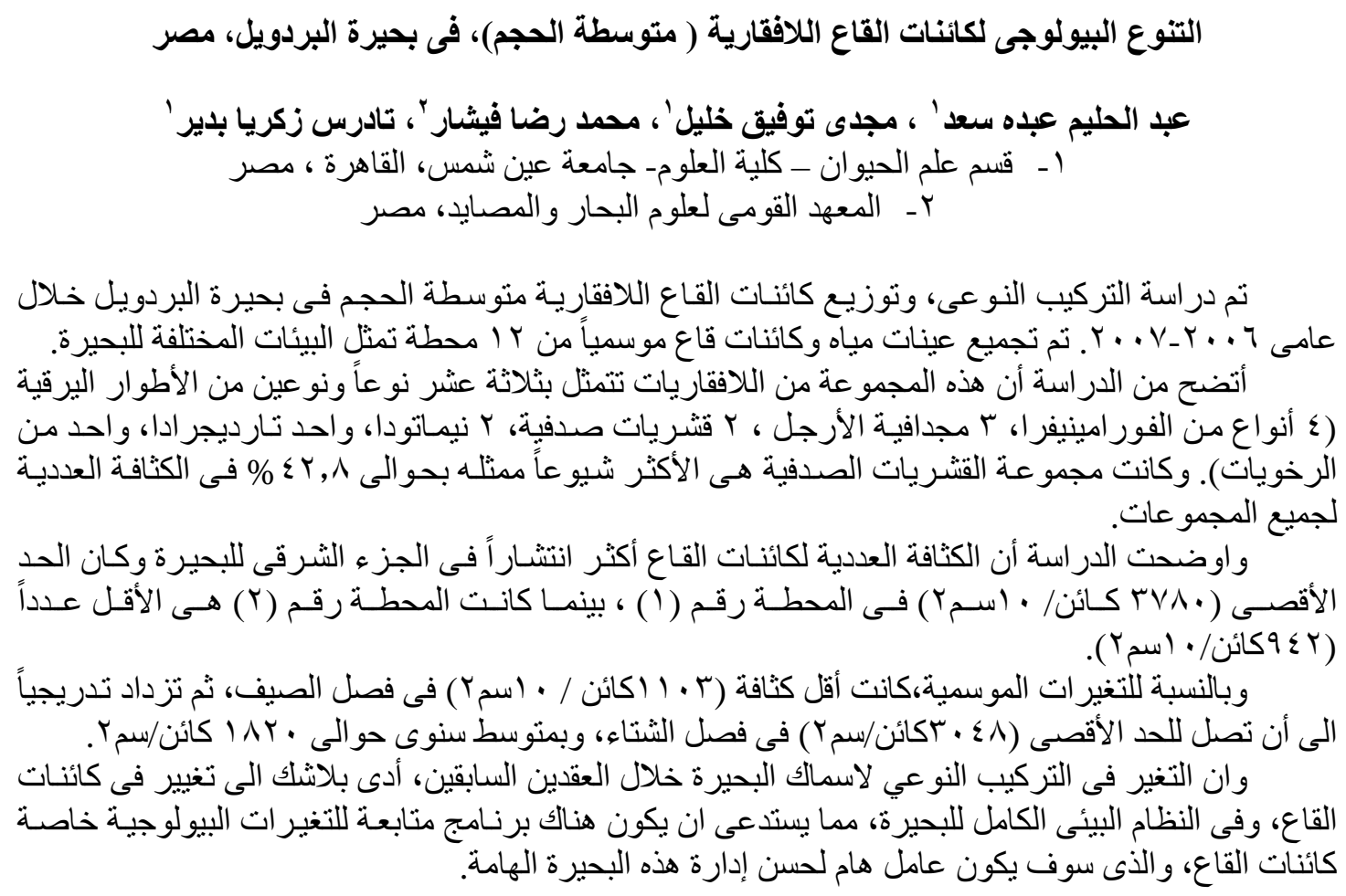

